\title{
Principles and Regularities of Functioning of the Organizational and Economic Mechanism of Land Tenure and Land Use in the Digital Economy
}

\author{
Lyudmila Pototskaya*, Nadezhda Ukolova, and Nadezhda Novikova
}

Saratov State Agrarian University named after N.I. Vavilova, 1, Teatralnaya Square, Saratov, 410600, Russian Federation

\begin{abstract}
The basis for development of an optimal organizational and economic mechanism for land tenure and land use adapted to the conditions of the digital economy is based on the principles and patterns of its regulation through the identification and application of effective areas of administrative influence at the federal level through use of innovative tools. The analysis of the distribution of the land fund of the Russian Federation by land categories for 2016-2020 is carried out and the need to solve some of the fundamental problems of formation of the mechanism under consideration through use of the identified development patterns formed by the regulatory, economic and digital environment for its regulation, considering the dynamics of changes in the category of agricultural land within the study period is confirmed. It has been established that interaction of subjects of land relations depends on the degree of practical and scientific substantiation of the organizational and economic mechanism of land tenure and land use, the functional state of the digital and institutional environment.
\end{abstract}

\section{Introduction}

We will start developing the principles of functioning of the organizational and economic mechanism of land tenure and land use in the digital economy by considering the fundamental directions of development of the program "Digital Economy of the Russian Federation" designed for implementation until 2024, formed in the context of the implementation of the Strategy for Development of the Information Society in the Russian Federation for 2017-2030 approved by the Decree of the President of the Russian Federation of May 9, 2017 No. 203 "On the Strategy for the Development of the Information Society in the Russian Federation for 2017-2030" [1, 2]. The functional features of the participants in the land tenure mechanism ensure the process of continuous interaction of the subjects at all stages of agricultural land use. Not only the study of the state of the land market and consideration of the commercial potential of interaction are

\footnotetext{
*Corresponding author: lpototskaya@bk.ru
} 
relevant, but also implementation of the identified digital economy tools used in land use. It is necessary to analyze the market conditions that ensure promotion and implementation of digital technologies in the land relations sector, consult all interested participants in the mechanism of land tenure and land use in effective cooperation that ensures the balance of interests.

\section{Methods}

The study methodology is based on dialectical and system-functional approaches to the study of the organizational and economic mechanism of land tenure and land use in the digital economy. In the process of the study, various methods of economic study were used: abstract-logical, monographic, economic-statistical, and computational-constructive.

\section{Results}

Let's define the basic directions of development of the digital economy in the Russian Federation that optimize the functioning of the organizational and economic mechanism of land use, these are:

- regulatory regulation that implies formation of an adapted legal environment, development and transfer of modern technologies that ensure effective economic activity in agricultural land use. Implementation of the above-mentioned direction is possible on the basis of creating a permanently functioning mechanism of land management in the sphere of regulating the digital economy, overcoming legal restrictions and creating an institutional environment that ensures use of effective digital tools regulating the land market, comprehensive legislative use of legal land relations, stimulating economic activity related to production of innovative products by land users, formation of a policy for development of a digital economy of land use in a single economic space and creation of a methodology for regulating the organizational and economic mechanism of land tenure;

- providing a mechanism for land use with human resources, providing for use of highly qualified human capital, which is in demand on the market in the digital economy through creation of prerequisites for training of competent personnel employed in the regime of effective land use, the labor market that meets modern requirements, the organization of a system of motivation for participation of personnel in development of the digital land use economy of Russia;

- formation of study competencies and technical groundwork in land use through application of a systematic approach that provides support for applied study in the digital economy and development of innovative areas of the land use mechanism, as well as formation of an institutional environment that ensures the development and implementation of study in the digital economy of land use;

- development of the information infrastructure for the functioning of the organizational and economic mechanism of agricultural land use ensured by formation of an effective information space, meeting the needs of the economy for accumulation and transfer of data to land users for production of innovative agricultural products and digital technologies of effective agriculture, creation of a set of centers for systematization, storage, processing and transfer of information resources to mechanism subjects, introduction of digital platforms for working with information arrays of agricultural land use;

- ensuring information security of the functioning of the organizational and economic mechanism of land tenure and land use, which implies the protection of the state, society and each subject of land relations from possible endogenous and exogenous information 
threats by ensuring uniform security at all levels of the information space, organizational and legal protection of the interaction of subjects of land relations in digital economy.

The digital economy as a tool for optimizing the land use mechanism can be viewed through a three-level system, the elements of which interact in a single information field. The first level is land markets and areas of activity, where subjects enter into certain mutually beneficial relationships, each pursuing its own goals. The second level is a set of platforms and technologies for formation of competencies for development of sectors of the agricultural economy and land markets. The third level is an environment that provides the conditions for formation of the above platforms, which presupposes regulatory regulation, development of information infrastructure and security, and the effective use of human resources.

Let us analyze the distribution of the land fund of the Russian Federation by land category for 2016-2020 (Table 1). According to the Federal Service of State Registration, Land Register and Mapping report on the state and use of land in Russia in 2019, the area of the land fund of the Russian Federation as of January 01, 2020 amounted to $1,712,519.1$ thousand hectares $[3,4,5]$.

Table 1. Distribution of the land fund of the Russian Federation by land categories for 2016-2020 (thousand ha).

\begin{tabular}{|c|c|c|c|c|c|c|}
\hline $\begin{array}{c}\text { Land } \\
\text { categories }\end{array}$ & 2016 & 2017 & 2018 & 2019 & 2020 & $\begin{array}{c}2020 \text { in } \\
\% \text { to } \\
2016\end{array}$ \\
\hline $\begin{array}{l}\text { Agricultural } \\
\text { land }\end{array}$ & \begin{tabular}{|c|}
383,73 \\
8.3 \\
\end{tabular} & $\begin{array}{c}383,612 \\
.0 \\
\end{array}$ & $383,227.7$ & $382,509.8$ & $381,673.0$ & 99.5 \\
\hline $\begin{array}{c}\text { Lands of } \\
\text { settlements }\end{array}$ & $\begin{array}{c}20,327 \\
4\end{array}$ & $\begin{array}{c}20,377 . \\
5\end{array}$ & $20,453.0$ & $20,501.6$ & $20,551.7$ & 101.1 \\
\hline $\begin{array}{c}\text { Lands of } \\
\text { industry and } \\
\text { other social } \\
\text { purposes }\end{array}$ & $\begin{array}{c}17,337 . \\
1\end{array}$ & $\begin{array}{c}17,420 . \\
2\end{array}$ & $17,454.9$ & $17,511.6$ & $17,614.8$ & 101.6 \\
\hline $\begin{array}{c}\text { Lands of } \\
\text { specially } \\
\text { protected areas } \\
\text { and objects }\end{array}$ & $\begin{array}{c}47,032 . \\
8\end{array}$ & $\begin{array}{c}47,251 . \\
0\end{array}$ & $47,694.2$ & $49,641.7$ & $49,646.4$ & 105.6 \\
\hline Forest lands & $\begin{array}{c}1,126,3 \\
20.3 \\
\end{array}$ & $\begin{array}{c}1,126,2 \\
59.5 \\
\end{array}$ & $\begin{array}{c}1,126,288 \\
.6 \\
\end{array}$ & $\begin{array}{c}1,125,786 \\
.2 \\
\end{array}$ & \begin{tabular}{|c|}
$1,126,643$ \\
.0 \\
\end{tabular} & 100.0 \\
\hline $\begin{array}{l}\text { Water fund } \\
\text { lands }\end{array}$ & \begin{tabular}{|c}
$28,054$. \\
8 \\
\end{tabular} & $\begin{array}{c}28,070 . \\
4 \\
\end{array}$ & $28,069.9$ & $28,070.0$ & $28,069.4$ & $100, .1$ \\
\hline Reserve land & $\begin{array}{c}89,708 . \\
4\end{array}$ & $\begin{array}{c}89,528 . \\
5\end{array}$ & $89,330.8$ & $88,498.2$ & $88,320.8$ & 98.5 \\
\hline
\end{tabular}

According to Table 1, for the entire period of the study, the largest share in the structure of the land fund of the Russian Federation is occupied by the category of forest land $(65.8 \%)$, the second place in terms of area is occupied by agricultural land (from $22.3 \%$ to $22.4 \%)$. There is a slight decrease in agricultural land in 2020 relative to $2016(0.5 \%)$ and reserve land $(1.5 \%)$, the proportion of land in settlements, land for industry and other social purposes, land of specially protected areas and facilities, lands of the water fund increased by $1.1 \%, 1.6 \%, 5.6 \%, 0.1 \%$, respectively.

Figure 1 shows the dynamics of distribution of agricultural land in the Russian Federation for 2016-2020. 


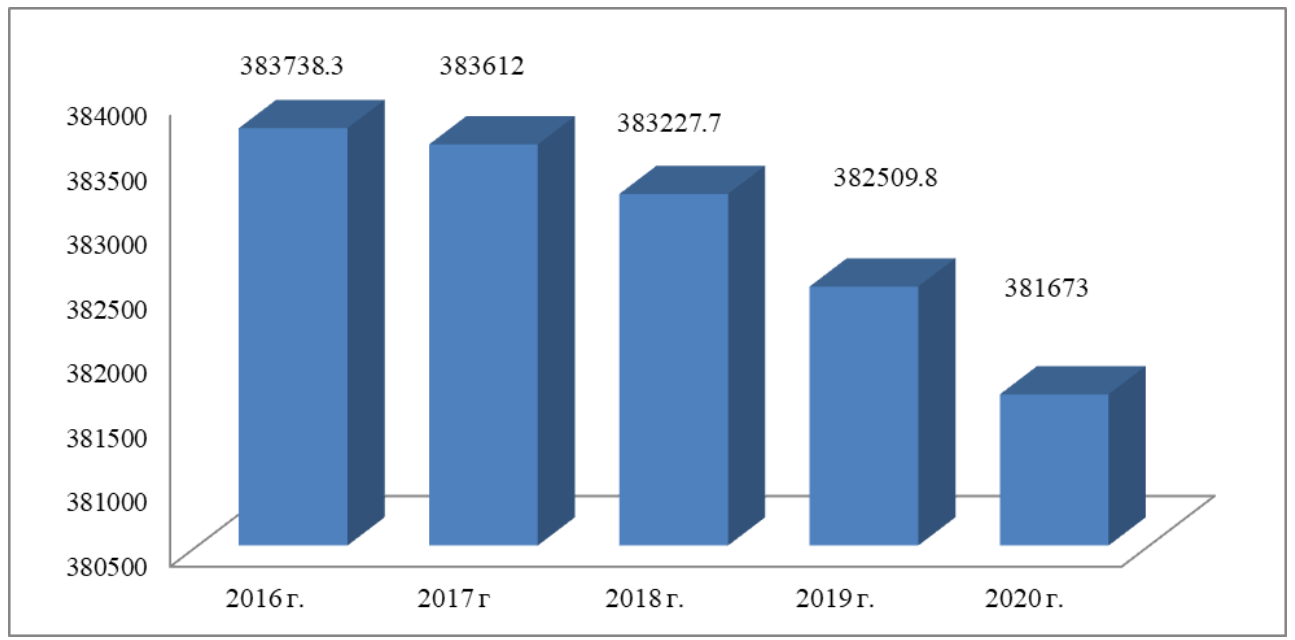

Fig. 1. Dynamics of distribution of agricultural land in the Russian Federation for 2016-2020 (thousand ha).

Analyzing the data in Figure 1, we note the trend of reduction in the category of agricultural land in the study period by $2,065.3$ thousand hectares. In order to ensure the stable functioning of the land market, the principles of the functioning of the organizational and economic mechanism of land tenure and land use identified in the study, considering development of the digital space, have been grouped on three grounds: regulatory support for the functioning of the mechanism, development of the infrastructural environment of the organizational and economic mechanism of land use, ensuring cooperation of the digital sector and the land use sector in the agricultural economy (Figure 2). 
PRINCIPLES OF FUNCTIONING OF THE ORGANIZATIONAL AND ECONOMIC MECHANISM OF LAND TENSE AND LAND USE IN THE CONDITIONS OF THE DIGITAL ECONOMY

\section{Principles of regulatory support for the mechanism functioning}

Rules and regulations recording the incentives for effective land use, cooperation of the subjects of the organizational and economic mechanism for

Provisions of civil, administrative, labor law that determine the framework for functioning of the organizational and economic mechanism of land tenure and

\section{Principles for development of the infrastructural environment of the organizational and economic mechanism of land use}

Legislative, regulatory and methodological support for the activities of

Organization of infrastructure, creation of digital centers, innovative networks ensuring effective interaction of participants in the organizational and economic mechanism of land tenure and land use

Formation of organizations that optimize the process of functioning the mechanism of land tenure and land use

\section{Principles for ensuring cooperation between the digital and land sectors in} the agricultural economy

Implementation of programs to support digitalization of the land use

Creation of innovative associations, providing financial incentives for

Access to advanced technologies and highly qualified workforce, reduction of time and financial costs for maintaining the effective functioning of the organizational and economic mechanism of land use

Fig. 2. The principles of functioning the organizational and economic mechanism of land tenure and land use in the digital economy.

The principles outlined in Figure 2 imply the functioning of the organizational and economic mechanism of land tenure and land use with emergence of utility (economic benefit from the use) of land, assessment of the investment attractiveness of land use, state land management, an institutional form of land relations development, determined by the rules of transformation of land relations and land management. resources in agriculture.

\section{Discussion}

The scientific provisions of the classic economists are of great importance for development of organizational and economic mechanism of land tenure and land use: A . Smith, D. Ricardo), A . Marshall)? and the most famous modern scientists: A.I. Altukhova, N.I. Buzdalova, S.N. Volkova, A.V. Petrikova, A.M. Yugaya and others. The existing interest in 
the efficient use of agricultural land and its sustainability testify to the importance of this problem. However, due to the changing political, socio-economic conditions, many issues related to the study topic are not sufficiently developed and require further improvement in scientific and practical terms.

When summarizing the above, it is possible to single out the patterns that hinder the functioning of the organizational and economic mechanism of land tenure and land use and development of the agricultural land market, accumulated in three groups: administrative, mediated by the irrational state management of development of the digital economy of land relations; economic, due to unfavorable conditions in the land market; personal, arising from the unskilled use of the labor potential of the land use sector.

The positive patterns of functioning the organizational and economic mechanism of land tenure and land use that have developed in the context of the digitalization of the economy are grouped in the following areas: political, due to development of the country's regulatory and legal framework and the political situation; information security, depending on the current level of legislative support for the protection of interaction within the Internet sphere; economic, provided by favorable land market conditions; scientific, determined by the ability to use and develop the innovative potential of land use; social, acting as a result of infrastructural and demographic changes; global, resulting from the reaction to overcoming the inhibition of the development of the country's land market.

\section{Conclusion}

The program "Digital Economy of the Russian Federation" involves creation of an information field, where digital data will be an important factor of production in the considered organizational and economic mechanism of land tenure and land use, ensuring effective interaction of individuals, legal entities, the state, the scientific and educational community. The effective implementation of the program is possible by eliminating the existing institutional obstacles to creation and sale of agricultural land use products by providing appropriate infrastructural conditions, digital tools mediating the growth of the competitiveness of agricultural products within the country and development of the land market.

To ensure the optimal functioning the organizational and economic mechanism of land tenure and land use, a systemic compensatory state approach is required to solve the problem of the progressive development of the agricultural land market, leveling the revealed negative trend of reducing the category of agricultural land $(2,065.3$ thousand hectares) in the study period. This will ensure the intensification of interaction between the subjects of the land market, an increase in the scope of products produced by effective land owners, and an improvement in its sales. Important factors mediating the formation of the agricultural land market and regulating the organizational and economic mechanism of land use are: legal relations associated with the ownership of agricultural land, flows of information resources promoted by the tools of the land use digital economy.

\section{References}

1. Rasporyazhenie Pravitel'stva Rossijskoj federacii ot 28 iyulya 2017 g. № $1632-\mathrm{R}$ «O utverzhdenii prilagaemoj programmy «Cifrovaya ekonomika Rossijskoj Federacii»»» (Moskva, 2017)

2. Poyasnitel'naya zapiska $\mathrm{k}$ predlozheniyu o realizacii novogo napravleniya programmy «Cifrovaya ekonomika Rossijskoj Federacii» (Moskva, 2017) 
3. Gosudarstvennyj (nacional'nyj) doklad o sostoyanii i ispol'zovanii zemel' v Rossijskoj Federacii v 2017 (Moskva, 2017)

4. Gosudarstvennyj (nacional'nyj) doklad o sostoyanii i ispol'zovanii zemel' v Rossijskoj Federacii v 2018 godu (Moskva, 2018)

5. Gosudarstvennyj (nacional'nyj) doklad o sostoyanii i ispol'zovanii zemel' v Rossijskoj Federacii v 2019 godu (Moskva, 2019)B. Agarwal, P. Anthwal, M. Mahesh, Journal of Development Studies, 57, 11 (2021)

6. F. D. Bardgett, Journal of Scottish Historical Studies, 41, 1 (2021)

7. V. F. Blokhin, Vestnik Sankt-Peterburgskogo Universiteta, Istoriya, 66, 3 (2021)

8. D. E. Hamilton, Agricultural History, 95, 2 (2021)

9. L. L. Hunt, Du Bois Review, 18, 2 (2021)

10. P. Jiménez-Castillo, I. Camarero, Al-Qantara, 42, 1 (2021)

11. Y. Jiping, Journal of Chinese Humanities, 6, 2 (2021)

12. M. Manzanelli, HiSTOReLo, 13, 26 (2021)

13. B. B. Nara, M. Lengoiboni, J. Zevenbergen, Land use Policy, 104 (2021)

14. B. Rubio, J. Peña, Caderno CRH, 34 (2021) 